\title{
SERUM C-PEPTIDE LEVEL IN OBESE AND NON-OBESE PATIENTS WITH TYPE 2 DIABETES MELLITUS
}

\author{
Shamha Beegum Mariyam¹, Saboora Beegum Muthubeevi², Sandhya Chandrasekharan Vasantha ${ }^{3}$
}

${ }^{1}$ Assistant Professor, Department of Biochemistry, Government Medical College, Thiruvananthapuram, Kerala.

2 Professor, Department of Biochemistry, Government Medical College, Thiruvananthapuram, Kerala.

${ }^{3}$ Associate Professor, Department of Biochemistry, Government Medical College, Thiruvananthapuram, Kerala.

\section{ABSTRACT}

\section{BACKGROUND}

C-peptide is a reliable indicator of endogenous insulin secretion in type 2 diabetes mellitus. The worldwide explosion of obesity has resulted in an ever increasing prevalence of Type 2 Diabetes Mellitus (T2DM). Hyperinsulinaemia and insulin resistance are often emphasised as characteristics of T2DM. Obesity is associated with insulin resistance, thus highlighting the importance of lifestyle modifications in the management of T2DM.

\section{MATERIALS AND METHODS}

30 obese and 30 non-obese T2DM patients in the age group 18 - 65 years were selected for the study based on their body mass index. Their basal C-peptide level in serum was assayed by ELISA technique. Fasting blood glucose and HbA1c were assayed to assess the glycaemic status of the study subjects. Statistical analysis was done using SPSS version 22.0. Quantitative data were expressed as mean and SD and quantitative data for the two groups were compared with unpaired ' $t$ ' test. Association between $C$ peptide and other parameters was assessed by Pearson correlation. P value less than 0.05 is considered significant.

\section{RESULTS}

The obese T2DM patients had higher basal C-peptide values compared to the non-obese patients. Mean C-peptide of obese group was $6.31 \pm 2.2 \mathrm{ng} / \mathrm{mL}$ and that of the non-obese group was $3.53 \pm 2.7 \mathrm{ng} / \mathrm{mL}$. Mean C-peptide of the obese group was significantly higher than that of the non-obese group $(p<0.05)$. There was no significant difference in FBS between the two groups (p > 0.05) Mean $\mathrm{HbA1c}$ of the obese group was 6.9 and that of the non-obese group was 6.0. The difference observed is statistically significant $(p<0.05)$. This is suggestive of poor control of glucose in the obese due to insulin resistance.

\section{CONCLUSION}

Higher C-peptide levels in obese T2DM patients denote insulin resistance, which highlights the importance of lifestyle modifications in the management of T2DM.

\section{KEYWORDS}

C-peptide, T2DM, Obesity, Insulin Resistance.

HOW TO CITE THIS ARTICLE: Mariyam SB, Muthubeevi SB, Vasantha SC. Serum C-peptide level in obese and non-obese patients with type 2 diabetes mellitus. J. Evolution Med. Dent. Sci. 2017;6(5):350-353, DOI: 10.14260/Jemds/2017/79

\section{BACKGROUND}

Diabetes mellitus is described as one of the main threats to human health in the twenty first century. Type 2 Diabetes Mellitus (T2DM) comprises approximately $90 \%$ of all cases of diabetes mellitus.(1) According to WHO epidemiology reports, the number of adults with T2DM will rise from 135 million in 1995 to 300 million in 2025.(2) The prevalence of T2DM is rising rapidly because of increasing obesity and reduced activity levels as countries become more industrialised(3); $60 \%-80 \%$ of patients with T2DM are obese.(4) Obesity is associated with an increased risk of developing insulin resistance, which is a risk factor for T2DM.(5) Insulin resistance is characterised by decreased ability of insulin to act on peripheral tissues. Here, insulin concentration is rather

Financial or Other, Competing Interest: None.

Submission 07-12-2016, Peer Review 02-01-2017,

Acceptance 09-01-2017, Published 16-01-2017.

Corresponding Author:

Dr. Shamha Beegum Mariyam,

Assistant Professor,

Department of Biochemistry,

Government Medical College,

Thiruvananthapuram, Kerala, India.

E-mail:drshamha@gmail.com

DOI: $10.14260 /$ jemds $/ 2017 / 79$ higher than that in those with normal glucose tolerance indicating that insulin resistance rather than insulin deficiency is the fundamental defect in obesity and T2DM. This is followed by beta cell dysfunction in due course of time, as the beta cells fail to keep up with the body's need for insulin. Insulin resistance precedes the derangement in insulin secretion and clinical diabetes by as much as 20 years.(6) Obesity itself can accelerate the progressive decline in beta cell function in patients with T2DM.(7)

Insulin level in blood may be assayed to monitor the amount of insulin secreted by the beta cells and to check for insulin resistance.(8) With the rising incidence of T2DM in younger patients and development of new therapies aimed at preserving insulin secretion, the measurement of insulin secretion is becoming increasingly relevant. Assay of serum insulin as a measure of insulin secretion has several limitations. Recent evidence proves that C-peptide, a cleavage product released into the circulation during insulin synthesis can be used as an indicator of insulin secretion. C-peptide is a 31 amino-acid peptide that links the A chain and B chain in the proinsulin molecule. It facilitates the efficient assembly, folding and processing of insulin in the endoplasmic reticulum. It is cleaved from proinsulin and stored in secretory granules of beta cells of pancreas to be released into the blood stream in amounts equimolar with those of 
insulin. The physiology of C-peptide makes it appropriate for assessing insulin secretion. It is less susceptible to hepatic degradation with a half-life 2 - 5 times longer than that of insulin, is free from interference with insulin antibodies and allows discrimination of endogenous and exogenous sources of Insulin.(9) Hence, it is a more reliable indicator of insulin secretion than insulin itself.

C-peptide was initially thought to be an inactive substance. Its role in diabetes management has been expanding for the past few decades. It has recently been shown to be a biologically active peptide which corrects vascular, neural and renal dysfunction in patients with Type 1 Diabetes Mellitus (T1DM). Replacement therapy with Cpeptide has been shown to ameliorate the microvascular complications, especially nephropathy, neuropathy and retinopathy in T1DM.(10) Similar studies in T2DM patients are limited. A comparative study of basal serum C-peptide levels between obese and non-obese patients with T2DM will help us to compare the insulin secretion in the obese and nonobese patients as one $\mathrm{C}$-peptide molecule is released into the circulation with the secretion of each insulin molecule. The role of obesity in the pathogenesis of insulin resistance and thereby T2DM can be assessed. A high C-peptide level denotes insulin resistance and a low level denotes beta cell dysfunction. This will help us to alter the modality of treatment by incorporating lifestyle changes that can reverse insulin resistance by increasing insulin sensitivity.

\section{MATERIALS AND METHODS}

This was a cross-sectional study carried out in the Diabetic Clinic of Government Medical College, Thiruvananthapuram. The study was conducted after getting approval from Institutional Ethics Committee according to the provisions of Helsinki declaration. A written informed consent was obtained from the participants. The study subjects included 60 diagnosed T2DM patients between 18 - 65 years of age. The study sample was selected on a random basis. They were grouped into obese and non-obese based on the WHO criteria of obesity in adult Asians. (11)

Body mass index was calculated from the formula: $\mathrm{BMI}=$ Body Weight in $\mathrm{Kg} /$ Height in $\mathrm{m}^{2}$. Those with a BMI $>25$ were grouped as obese and those with a BMI $<25$ were grouped as non-obese.

Patients with acute infections, renal failure, hypertension, polycystic ovarian syndrome and pregnancy were excluded from the study.

\section{Collection of Blood Samples}

$6 \mathrm{~mL}$ venous blood was drawn in a fasting condition, under strict aseptic precautions. Blood for C-peptide assay was collected in plain sample tubes, blood for FBS estimation in bottles containing sodium fluoride and blood for $\mathrm{HbA} 1 \mathrm{c}$ estimation in EDTA bottles. Serum for C-peptide assay was separated by centrifugation and kept at $-20^{\circ} \mathrm{C}$ until analysis.

C-peptide assay was done using ELISA kit from DRG Industries. C-Peptide ELISA is a solid phase enzyme-linked immunosorbent assay, based on the principle of competitive binding. Microtitre wells are coated with anti-mouse antibodies, which bind a monoclonal antibody directed towards a unique antigenic site on the C-peptide molecule. Endogenous C-peptide of a patient sample competes with a Cpeptide - horseradish peroxidase conjugate for binding to the coated antibody. The amount of bound peroxidase conjugate is inversely proportional to the concentration of $\mathrm{C}$-peptide in the sample. After addition of the substrate solution, the intensity of colour developed is inversely proportional to the concentration of $\mathrm{C}$-peptide in the patient sample. Normal serum C-peptide value was found to be $0.5-3.2 \mathrm{ng} / \mathrm{mL}$.(12)

Blood glucose was assayed by glucose oxidase method(13) in fully automated clinical chemistry analyser manufactured by Transasia Biomed.

HbA1c was estimated by Ion exchange resin method(14) to assess the glycaemic status of the patients over the previous 6 - 8 weeks.

Statistical analysis was done using SPSS version 22.0. Quantitative data were expressed as Mean and Standard deviation. Qualitative data were expressed as proportion and compared by chi-square test. Quantitative data for the two groups were compared with unpaired ' $t$ ' test. Association between C-peptide and other parameters was assessed by Pearson correlation. $\mathrm{P}$ value less than 0.05 is considered significant. Multiple linear regression model was done to assess the independent predictors of C-peptide.

\section{RESULTS}

The study group consisted of 60 T2DM patients, of which 30 were obese and 30 were non-obese. The subjects in the present study were aged between 34 and 65 years. Out of these 23 were in the age group 50 - 59 years and 21 were over 60 years of age. Majority of the obese patients were in the age group 50 - 59 years $(43.3 \%)$ and majority of the nonobese were above 60 years of age $(46.7 \%)$. Mean age of the obese group is $52.3 \pm 8.1$ years and that of the non-obese group is $56.0 \pm 8.0$ years; the observed difference was not statistically significant $(\mathrm{p}>0.05)$. There was a female preponderance in the study population. There were 46 females (76.7\%) and 14 males (23.3\%); $90 \%$ of the obese and $63.3 \%$ of the non-obese were females and $10 \%$ of the obese and $36.7 \%$ of the non-obese were males.

FBS of the study population ranged from 87 to 360 $\mathrm{mg} / \mathrm{dL} ; 35 \%$ had an FBS between 100 and $150 \mathrm{mg} / \mathrm{dL}$ and 25\% had an FBS between 150 and $199 \mathrm{mg} / \mathrm{dL}$. Mean FBS of the study population was $175.53 \pm 67.89 \mathrm{mg} / \mathrm{dL}$. Mean FBS in the obese group was $190.23 \pm 72.81 \mathrm{mg} / \mathrm{dL}$ and that in the non-obese group was $160.83 \pm 60.23 \mathrm{mg} / \mathrm{dL}$. There was no significant difference in FBS between the two groups ( $p>$ 0.05).

$18 \%$ of the study population had an HbA1c level above $8 \%$, which included $26.7 \%$ of the obese and $10 \%$ of nonobese patients indicating poor control of diabetes mellitus. There was significant difference in mean HbA1c level between obese and non-obese T2DM patients (Table 1). Obese T2DM patients had comparatively higher HbA1c levels than the non-obese $(\mathrm{p}<0.05)$.

$65 \%$ of the study population had a C-peptide value above $3.2 \mathrm{ng} / \mathrm{mL}$ and $35 \%$ had a value between 0.5 and $3.2 \mathrm{ng} / \mathrm{mL}$; $93.3 \%$ of the obese patients had a C-peptide value above 3.2 $\mathrm{ng} / \mathrm{mL}$, while only $36.7 \%$ of the non-obese had a C-peptide value above $3.2 \mathrm{ng} / \mathrm{mL}$. The observed difference in C-peptide value between obese and non-obese was statistically significant $(p<0.05)$. Mean $C$-peptide of the obese group was significantly higher than that of the non-obese group ( $p<$ 0.05) (Table 2). Correlation of C-peptide with other variables showed significant positive correlation of C-peptide with BMI 
(Table 3, Figure 1) and FBS (Table 3, Figure 2) with a p < 0.05 . Serum C-peptide showed weak correlation with age and HbA1c. Multiple linear regression model for C-peptide was done with the factors identified during univariate analysis. Cpeptide is shown to be associated with obesity even after adjusting for $\mathrm{HbA1c}$, age and sex differences between the groups and the adjusted difference is statistically significant $(b=2.681)(p<0.001)$.

\begin{tabular}{|c|c|c|c|c|c|}
\hline \multirow{2}{*}{$\begin{array}{l}\text { Study } \\
\text { Group }\end{array}$} & \multirow{2}{*}{$\mathbf{N}$} & \multicolumn{2}{|c|}{$\mathrm{HbA}_{1} \mathrm{C}$} & \multirow{2}{*}{$\mathbf{t}$} & \multirow{2}{*}{$\mathbf{p}$} \\
\hline & & Mean & SD & & \\
\hline Obese & 30 & 6.9 & 1.4 & \multirow{3}{*}{2.585} & \multirow{3}{*}{0.012} \\
\hline Non-Obese & 30 & 6.0 & 1.2 & & \\
\hline Total & 60 & 6.45 & 1.37 & & \\
\hline $\begin{array}{r}T \\
\text { amon }\end{array}$ & $C$ & paris & Me & bA1c & \\
\hline
\end{tabular}

\begin{tabular}{|c|c|c|c|c|}
\hline Study Group & Mean & SD & t & p \\
\hline Obese & 6.31 & 2.2 & & \\
\cline { 1 - 3 } Non-Obese & 3.53 & 2.7 & 4.32 & 0.001 \\
\hline Total & $\mathbf{4 . 9 2}$ & $\mathbf{2 . 8 5}$ & & \\
\hline Table 2. Comparison of Mean C-Peptide \\
Level among Obese and Non-Obese T2DM Patients \\
\hline
\end{tabular}

\begin{tabular}{|c|c|c|}
\hline Variable & Pearson Correlation & $\mathbf{p}$ \\
\hline Age & 0.074 & 0.572 \\
\hline BMI & 0.441 & $0.001^{*}$ \\
\hline FBS & 0.334 & $0.009 *$ \\
\hline HbA1c & 0.246 & 0.058 \\
\hline \multicolumn{3}{|c|}{$\begin{array}{l}\text { Table 3. Correlation of C-Peptide with } \\
\text { other Study Variables *-Significant }\end{array}$} \\
\hline
\end{tabular}

\begin{tabular}{|c|c|c|c|c|}
\hline Variable & $\begin{array}{c}\text { Regression } \\
\text { Coefficient (b) }\end{array}$ & $\begin{array}{c}\text { Std. } \\
\text { Error }\end{array}$ & t & $\begin{array}{c}\text { P } \\
\text { value }\end{array}$ \\
\hline Obesity & $2.681^{*}$ & 0.713 & 3.762 & $<.001^{*}$ \\
\hline HbA1c & 0.173 & 0.254 & .681 & .499 \\
\hline Age & 0.064 & 0.041 & 1.583 & .119 \\
\hline Sex & 0.718 & 0.823 & .872 & .387 \\
\hline \multicolumn{4}{|c|}{$\begin{array}{c}\text { Table 4. Multiple Linear Regression } \\
\text { Model for C-Peptide }\end{array}$-Significant } \\
\hline
\end{tabular}

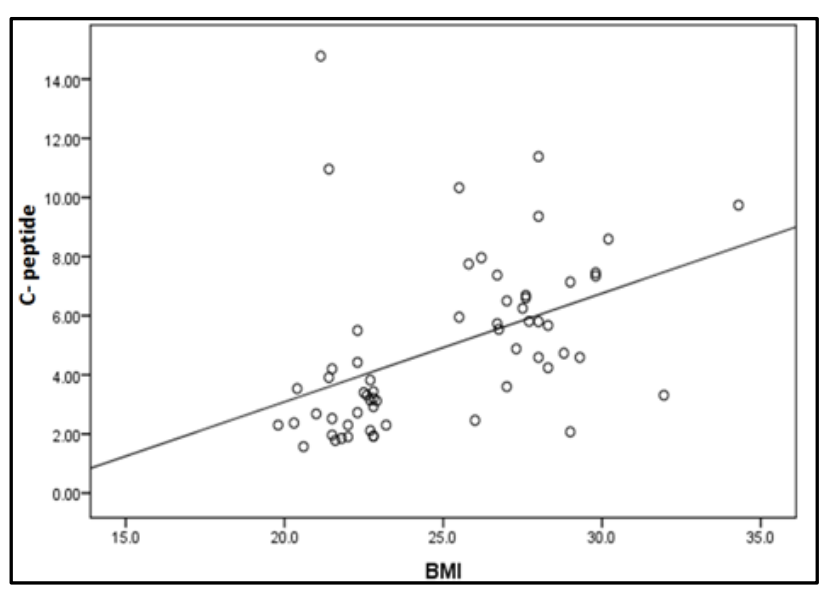

Figure 1. Correlation of C-Peptide with BMI

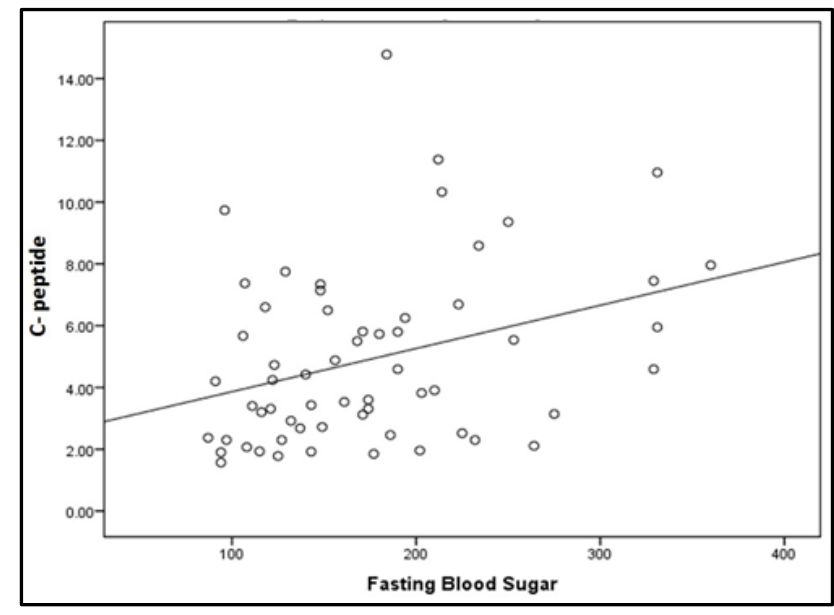

Figure 2. Correlation of C-Peptide with FBS

\section{DISCUSSION}

The present study has demonstrated that basal C-peptide level is significantly higher in obese T2DM patients compared to non-obese T2DM patients. This reflects a higher insulin secretion in them. This finding is in accordance with those reported by Sung Tae Kim et al, which showed that basal Cpeptide concentration is mainly influenced by BMI.(15) Similar results reported by Michael $\mathrm{H}$. Shanik et al concludes that obese patients are hyperinsulinaemic.(16)

Assay of fasting and post-glucose load of C-peptide levels in obese subjects by Enzo Bonora et al showed that the high C-peptide level seen in obesity is due to hyperinsulinaemia, which depends on pancreatic hypersecretion of insulin and Cpeptide in the fasting state.(17) The findings are in accordance with the observation by Olefsky et al that insulin resistance and hyperinsulinaemia are associated with obesity and both abnormalities improve after weight loss, thus highlighting the importance of lifestyle modifications in the management of T2DM.(18) Correlation of C-peptide with other variables showed positive correlation of basal C-peptide with BMI and FBS. As BMI increases, serum C-peptide also increases. The increased insulin indicated by elevated C-peptide is unable to control the blood sugar, probably due to insulin resistance. This is indicated by a high HbA1c level in the obese. A crosssectional study in the North Karnataka population yielded similar results.(19)

To prevent the development of T2DM, early detection of impaired glucose regulation may represent an appropriate strategy, as subjects with impaired glucose tolerance are at increased risk of developing T2DM.(20) Intervention studies have demonstrated that adoption of a healthy lifestyle characterised by healthy eating, regular physical activity and subsequent modest weight loss can prevent the progression of impaired glucose tolerance to clinical diabetes.(21)

The Diabetes Prevention Program Research Group suggests that future approaches to diabetes prevention should preferably include approaches that enhance insulin sensitivity.(22) Lifestyle modifications aimed at weight loss may result in providing a better glycaemic status in established T2DM. Prospective studies are needed to confirm the hypothesis that early therapeutic interventions aimed at reducing work load on beta cells and preserving even small residual beta cell secretion may modify the natural development of diabetes. Patients with adequate reserve may be managed with diet and exercise modalities to improve 
insulin sensitivity. C-peptide in replacement doses for short duration has been shown to improve the early stage functional and structural abnormalities of kidneys and peripheral nerves.(23) Further studies are required to assess the long-term therapeutic effects of C-peptide as T2DM is associated with loss of beta cell function in due course of time. C-peptide has been shown to cause disaggregation of insulin leading to enhanced physiological effects of insulin.(24) This needs to be proven by further studies, such that incorporation of C-peptide in the insulin schedule can be attempted for better glycaemic control.

\section{CONCLUSION}

The present study has succeeded in demonstrating higher levels of C-peptide in obese T2DM patients, which proves the presence of higher levels of insulin secretion in them compared to the non-obese group. In spite of this hyperinsulinaemia, control of blood sugar is poor in the obese group as suggested by the significantly higher HbA1c values in them. This positively demonstrates the presence of insulin resistance in this group. Thus, we conclude that obesity leads to insulin resistance and is an important risk factor for poor glycaemic control in T2DM.

\section{REFERENCES}

[1] Mohan V, Sandeep S, Deepa R, et al. Epidemiology of type 2 diabetes: Indian scenario. Indian J Med Res 2007;125(3):217-30.

[2] King H, Aubert RE, Herman WH. Global burden of diabetes, 1995-2025: prevalence, numerical estimates and projections. Diabetes Care 1998;21(9):1414-31.

[3] Sarah W, Gojka R, Anders G, et al. Global prevalence of diabetes: estimates for the year 2000 and projections for 2030. Diabetes Care 2004;27(5):1047-53.

[4] Khalood MM, Al-Mansouri MA. Prevalence of obesity among type 2 diabetic patients in Al-Khobar primary health care centre. J Fam Community Med 2003;10(2):49-53.

[5] Kahn SE, Hull RL, Utzschneider KM. Mechanisms linking obesity to insulin resistance and type 2 diabetes. Nature 2006;444(7121):840-6.

[6] Yoshifumi S. Beta cell dysfunction: its critical role in prevention and management of type 2 diabetes. World J Diabetes 2015;6(1):109-24.

[7] Yoshifumi S. Postprandial C-peptide to glucose ratio as a marker of beta cell function: implication for the management of type 2 diabetes. Int J Mol Sci 2016;17(5):744-52.

[8] Wahren J, Ekberg K, Johansson J, et al. Role of Cpeptide in human physiology. AJP Endo 2000;278(5):759-68.

[9] Jones AG, Hattersley AT. The clinical utility of Cpeptide measurement in the care of patients with diabetes. Diabet Med 2013;30(7):803-17.

[10] Johannson J, Ekberg K, Shafquat J, et al. Molecular effects of C-peptide. Biochem \& Biophys Res Commun 2002;295(5):1035-40.
[11] Erdembileg A, Kuninori S, Akiko N, et al. The new BMI criteria for Asians by the regional office for the western pacific region of WHO are suitable for screening of overweight to prevent metabolic syndrome in elder Japanese workers. J Occup Health 2003;45(6):335-43.

[12] Bonser AM, Garcia-Webb P. C-peptide measurement: methods and clinical utility. Crit Rev Clin Labo Serv 1984;19(4):297-352.

[13] Trinder P. Determination of blood glucose using an oxidase-peroxidase system with a non-carcinogenic chromogen. J Clin Pathology 1969;22(2):158-61.

[14] Nathan DM, Singer DE, Hurxthal K, et al. The clinical information value of glycosylated hemoglobin assay. N Eng J Med 1984;310(6):341-6.

[15] Sung TK, Byung JK, Dong ML, et al. Basal C-peptide as a surrogate marker of subclinical atherosclerosis in type 2 diabetic patients. Diabetes Metab J 2011;35(1):41-9.

[16] Shanik MH, Xu Y, Skrha J, et al. Insulin resistance and hyperinsulinemia: is hyperinsulinemia the cart or the horse? Diabetes care 2008;31(2):262-8.

[17] Enzo B, Ivana Z, Fabiana B, et al. Peripheral hyperinsulinemia of simple obesity: pancreatic hypersecretion or impaired insulin metabolism? J Clin Endocrinol Metab 1984;59(6):1121-7.

[18] Olefsky J, Reaven GM, Farquhar JW. Effects of weight reduction on obesity. Studies of lipid and carbohydrate and metabolism in normal and hyperlipoproteinemic subjects. J Clin Invest 1974;53(1):64-76.

[19] Bilal BA, Basanagouda SP, Thaseen A. Significance of Cpeptide in type 2 diabetics: a study in the North Karnataka population of India. Al Ameen J Med Sci 2010;3(1):65-78.

[20] Wabitsch M, Hauner H, Hertrampf M, et al. Type II diabetes mellitus and impaired glucose regulation in Caucasian children and adolescents with obesity living in Germany. Int J Obes 2004;28(2):307-13.

[21] Gillies CL, Abrams KR, Lambert PC, et al. Pharmacological and lifestyle interventions to prevent or delay type 2 diabetes in people with impaired glucose tolerance: systematic review and metaanalysis. BMJ 2007;334(7588):299.

[22] Kitabchi AE, Temprosa M, Knowler WC, et al. Role of Insulin secretion and sensitivity in the evolution of type 2 diabetes in the diabetes prevention program: effects of lifestyle intervention and metformin. Diabetes 2005;54(8):2404-14.

[23] Ahmad G, Reza SN. Pathological consequences of Cpeptide deficiency in insulin-dependent diabetes mellitus. World J Diabetes 2015;6(1):145-50.

[24] Shafqat J, Melles E, Sigmundsson K, et al. Proinsulin Cpeptide elicits disaggregation of insulin resulting in enhanced physiological insulin effects. Cell Mol Life Sci 2006;63(15):1805-11. 